\title{
A natural frameshift mutation in Campanula EIL2 correlates with ethylene insensitivity in flowers
}

\author{
Line Jensen ${ }^{\dagger}$, Josefine Nymark Hegelund ${ }^{*}{ }^{\dagger}$, Andreas Olsen ${ }^{\dagger}$, Henrik Lütken and Renate Müller
}

\begin{abstract}
Background: The phytohormone ethylene plays a central role in development and senescence of climacteric flowers. In ornamental plant production, ethylene sensitive plants are usually protected against negative effects of ethylene by application of chemical inhibitors. In Campanula, flowers are sensitive to even minute concentrations of ethylene.

Results: Monitoring flower longevity in three Campanula species revealed C. portenschlagiana (Cp) as ethylene sensitive, C. formanekiana (Cf) with intermediate sensitivity and C. medium $(\mathrm{Cm})$ as ethylene insensitive. We identified key elements in ethylene signal transduction, specifically in Ethylene Response Sensor 2 (ERS2), Constitutive Triple Response 1 (CTR1) and Ethylene Insensitive 3- Like 1 and 2 (EIL1 and EIL2) homologous. Transcripts of ERS2, CTR1 and EIL1 were constitutively expressed in all species both throughout flower development and in response to ethylene. In contrast, ElL2 was found only in $\mathrm{Cf}$ and $\mathrm{Cm}$. We identified a natural mutation in Cmeil2 causing a frameshift which resulted in difference in expression levels of ElL2, with more than 100-fold change between $\mathrm{Cf}$ and $\mathrm{Cm}$ in young flowers.

Conclusions: This study shows that the naturally occurring 7 bp frameshift discovered in Cmeil2, a key gene in the ethylene signaling pathway, correlates with ethylene insensitivity in flowers. We suggest that transfer of the eil2 mutation to other plant species will provide a novel tool to engineer ethylene insensitive flowers.
\end{abstract}

Keywords: Campanula, Deletion, Ethylene, Ethylene insensitive, EIL, EIN, Flower development

\section{Background}

Ethylene is a gaseous phytohormone involved in regulating processes of horticultural importance encompassing flower development, fruit ripening, abscission and leaf and flower senescence [1]. In the ethylene signal transduction pathway, ethylene perception is facilitated via a copper co-factor present in receptor proteins integrated in the endoplasmic reticulum (ER) [2, 3]. In Arabidopsis, receptor proteins comprising EThylene Response 1 (ETR1) and Ethylene Response Sensor 1 (ERS1) or ETR2, ERS2 and Ethylene INsensitive 4 (EIN4) have been characterised. They differ by the functionality of their kinase domains [4-6]. Ethylene receptors exist as dimers and physically interact with the negative regulator Constitutive Triple Response 1 (CTR1) [7]. The kinase activity of CTR1 is directed towards the C-

\footnotetext{
* Correspondence: jnh@plen.ku.dk

${ }^{\dagger}$ Equal contributors

Department of Plant and Environmental Sciences, Faculty of Science,

University of Copenhagen, Højbakkegård Allé 9-13, 2630 Taastrup, Denmark
}

terminal of Ethylene INsensitive 2 (EIN2), a positive regulator of the ethylene response [8-10]. Ethylene binding to receptors deactivates CTR1 and results in a dephosphorylation of EIN2 [10]. Subsequently, the C-terminal of EIN2 is cleaved and translocated from ER to the nucleus [11, 12] where Ethylene INsensitive 3/Ethylene Insensitive 3Like (EIN3/EIL)-dependent transcription and activation of the ethylene response occur [13-15].

Postharvest quality of many ornamental plants is sensitive to ethylene during production and distribution $[16,17]$. In climacteric plants, flower development is controlled by intrinsic rise in ethylene production and respiration which promotes flower development and senescence. Plant species with climacteric flower senescence are sensitive to exogenous ethylene and may exhibit accelerated petal or flower wilting upon exposure. Commercially important climacteric ornamental plants include carnations, orchids, Kalanchöe, Campanula and roses [18-21]. Endogenous ethylene production may arise due to natural floral development but also in response to stress, elevated $\mathrm{CO}_{2}$ 


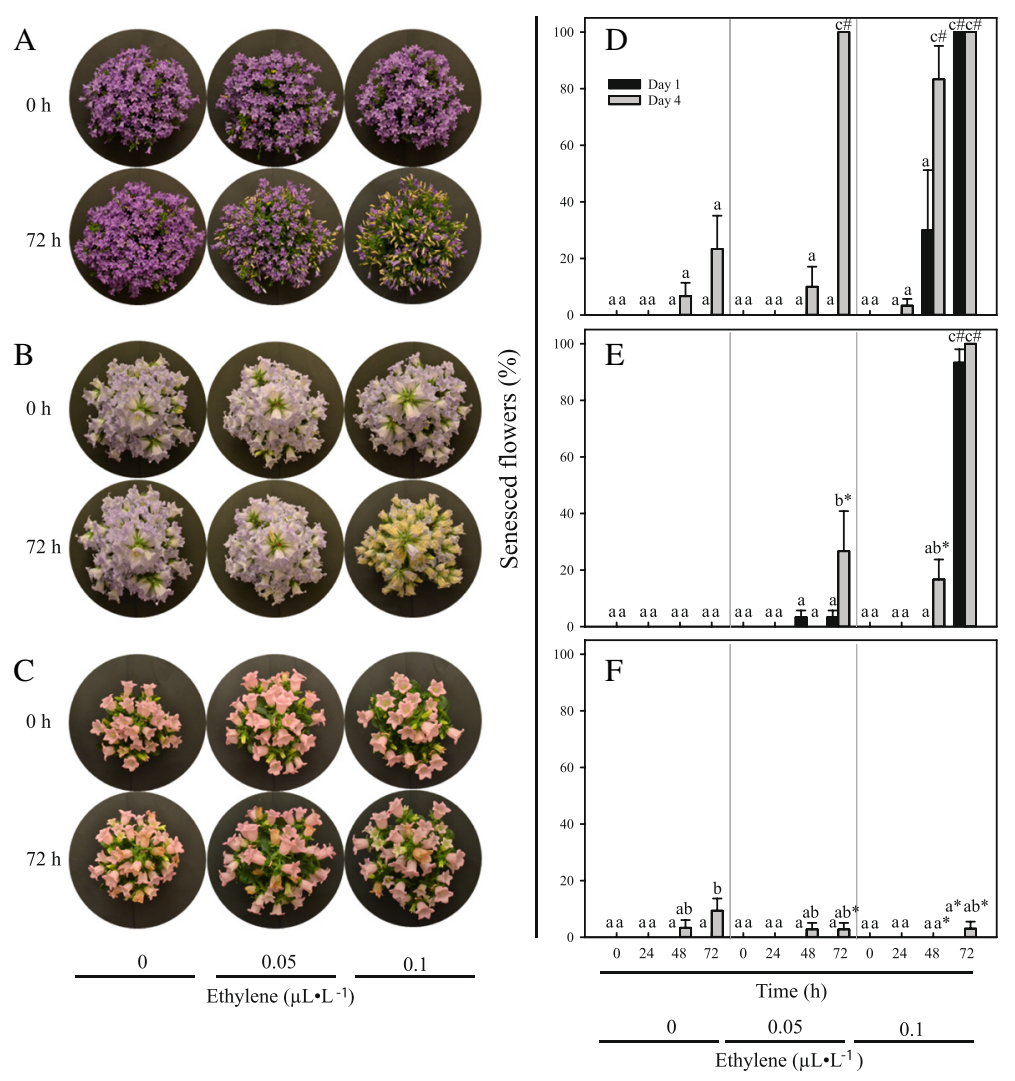

Fig. 1 Floral development in response to ethylene exposure in Campanula. Visual presentation of flower responses to ethylene concentrations of $0,0.05$ or $0.1 \mu \mathrm{L} \cdot \mathrm{L}^{-1}$ ethylene for $72 \mathrm{~h}$ a C. portenschlagiana $(\mathrm{Cp})$, b C. formanekiana (Cf), c C. medium (Cm). Graphical presentation of flower senescence (\%) in responses to ethylene concentrations of $0,0.05$ or $0.1 \mu \mathrm{L} \cdot \mathrm{L}^{-1}$ ethylene for $0-72 \mathrm{~h} \mathbf{d} C p, \mathbf{e} C f, \mathbf{f} C m$. Flower senescence were monitored every $24 \mathrm{~h}$ for 1-day (black) and 4-day (grey) old flowers. Data are means \pm SE. Values with same letters within species and are not significantly different $(P>0.05)$. Values with same symbols between species are not significantly different $(P>0.05)$

production [22] or increased auxin production [23]. Hence, ornamental plants are often treated with chemical inhibitors blocking ethylene signaling to improve postharvest quality and prolong flower longevity [24].

Genetic approaches designed to reduce ethylene sensitivity in flowers have modified signaling via the ethylene signal transduction pathway. The etr1-1 ethylene receptor mutant from Arabidopsis fails to bind ethylene [25]. Expression of etr1-1 in Petunia and Campanula carpatica flowers [26-28] results in ethylene insensitivity, delayed senescence and postponed flower abscission. Also, transgenic Petunia expressing reduced levels of PhEIN2 displayed delayed flower senescence [29]. However, to date genetic approaches successfully prolonging flower longevity have resulted in transgenic plants [30].

Campanula is an economically important ornamental plant, used as indoor potted plant, garden plant, as well as cut flower. The Campanula genus consists of

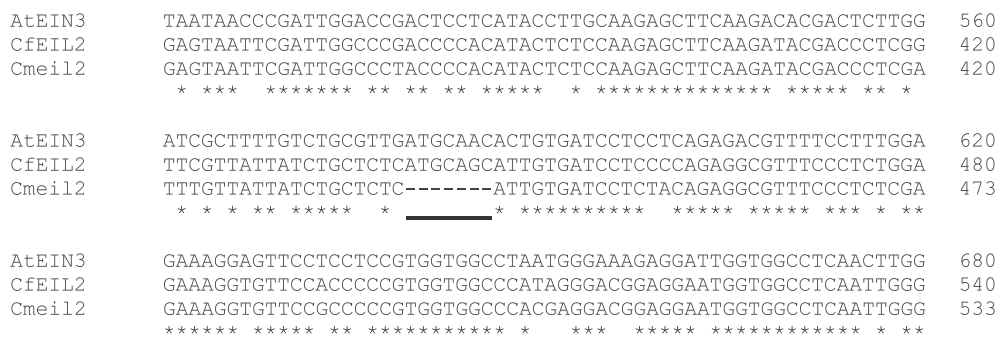

Fig. 2 Alignment of ElL2 gDNA from Campanula. The 65 bp fragments of Ell2 gDNA span the region where C. medium (Cm) contains a 7 bp deletion and C. formanekiana (Cf) does not. As a reference the closest ortholog AtEIN3 from Arabidopsis thaliana is included [Genbank: O24606.1]. The position of the deletion in Cmeil2 is underlined. The alignment was produced in Clustal $\Omega$ [62] 
approximately 415 species [31]. Here, we characterise expression patterns of flower expressed ERS, CTR and EIL genes in response to floral development and exogenous ethylene in three ornamental species of Campanula; $C$. portenschlagiana $(C p), C$. formanekiana $(C f)$ and $C$. medium $(\mathrm{Cm})$. The ethylene insensitivity identified in flowers of $C$. medium correlates with the occurrence of a natural mutation in the open reading frame of EIL2. This finding holds promise for new breeding strategies towards ethylene insensitive ornamental plants.

\section{Results}

\section{Campanula sensitivity to ethylene}

To understand the physiological variation in ethylene sensitivity among Campanula species, we used ethylene exposure tests in a postharvest environment. C. portenschlagiana, C. formanekiana and C. medium were selected due to their relevance as ornamental plants. $C p$ was found to be sensitive to ethylene from concentrations of $0.05 \mu \mathrm{L} \cdot \mathrm{L}^{-1}$. Individual flower sensitivity increased with flower age. In $C p$, old flowers did not survive $0.05 \mu \mathrm{L} \cdot \mathrm{L}^{-1}$ ethylene treatment for $48 \mathrm{~h}$ whereas young flowers maintained longevity in a $0.1 \mu \mathrm{L} \cdot \mathrm{L}^{-1}$ ethylene environment for more than 48 h. $C p$ flowers, regardless of age, did not survive after $72 \mathrm{~h}$ of the high ethylene treatment (Fig. 1a, d). Less pronounced ethylene sensitivity was found in $C f$ where $26 \%$ of old flowers wilted in response to $72 \mathrm{~h}$ of $0.05 \mu \mathrm{L} \cdot \mathrm{L}^{-1}$ ethylene as opposed to $100 \%$ of old $C p$ flowers. Increased ethylene concentration for the same period resulted in complete senescence of 4-day old $C f$ flowers (Fig. 1b, e). As in $C p$, young $C f$ flowers were less ethylene sensitive than old flowers, however, $93 \%$ of young flowers wilted in response to $0.1 \mu \mathrm{L} \cdot \mathrm{L}^{-1}$ ethylene (Fig. 1e). Thus, flowers of neither $C p$ nor $C f$ could tolerate $72 \mathrm{~h}$ of $0.5 \mu \mathrm{L} \cdot \mathrm{L}^{-1}$ ethylene, regardless of flower age. In contrast, $\mathrm{Cm}$ flowers were non-responsive to ethylene, they maintained both colour and turgor for $72 \mathrm{~h}$ in the $0.1 \mu \mathrm{L} \cdot \mathrm{L}^{-1}$ ethylene environment (Fig. 1c, f).

\section{Identification of key genes in ethylene signal transduction} Degenerate primers were used to identify expressed components in the ethylene signal transduction pathway in Campanula flowers. This allowed identification of partial homologs for ERS2, CTR1 and EIL. Campanula transcript fragments of ERS2 and CTR1 were translated to protein and named according to their closest relative in Arabidopsis (Additional files 1 and 2) whereas Campanula EIN3/ EIL homologs were named EIL1 and EIL2. Protein alignment of Campanula ERS2 showed high similarity within species in the identified region whereas Campanula CTR1 proteins differed (Additional files 1 and 2). In $C f$ and $C m, E R S 2$ was encoded by a single gene whereas $C p$ ERS2 was represented by two loci containing different
Table 1 Percent identity matrix of partial ElL nucleotide sequences from Campanula

\begin{tabular}{lllllll}
\hline & CpEIL1a & CpEIL1b & CfEIL1 & CmEIL1 & CfEIL2 & Cmeil2 \\
\hline CpEIL1a & 100 & & & & & \\
CpEIL1b & 93.06 & 100 & & & & \\
CfEIL1 & 88.49 & 86.95 & 100 & & & \\
CmEIL1 & 88.83 & 87.29 & 96.28 & 100 & & \\
CfEIL2 & 74.24 & 75.13 & 75.80 & 76.48 & 100 & \\
Cmeil2 & 73.08 & 73.80 & 74.14 & 75.51 & 96.31 & 100 \\
\hline
\end{tabular}

The identity matrix was produced by Clustal $\Omega$ [62]

Abbreviations: $C p$ C. portenschlagiana, Cf C. formanekiana, $\mathrm{Cm}$ C. medium

introns but resulting in identical partial transcripts (Additional file 3). Sequencing showed some polymorphisms among the partial CTR1 transcripts. These could not be separated in RT-PCR reactions and may represent different alleles in the same locus.

Also EIL transcripts were identified by degenerate primers using flower cDNA as template. Sequencing identified two partial EIL1 homologs EIL1a and EILIb in Cp and only one partial EIL1 homolog in $C f$ and $C m$. In $C f$ the cDNA pool contained an additional EIL homolog, EIL2, however this transcript was not readily detectable in $\mathrm{Cm}$ cDNA using the degenerate primers. As $C f$ and $C m$ have different sensitivities towards ethylene (Fig. 1e, f), primers were designed to separate and amplify both EIL1 and EIL2 fragments from $\mathrm{Cf}$ and $\mathrm{Cm}$ genomic DNA. Interestingly, Cmeil2 was found to contain a deletion of 7 bp in the EIL2 ORF resulting in a frame shift in the corresponding protein

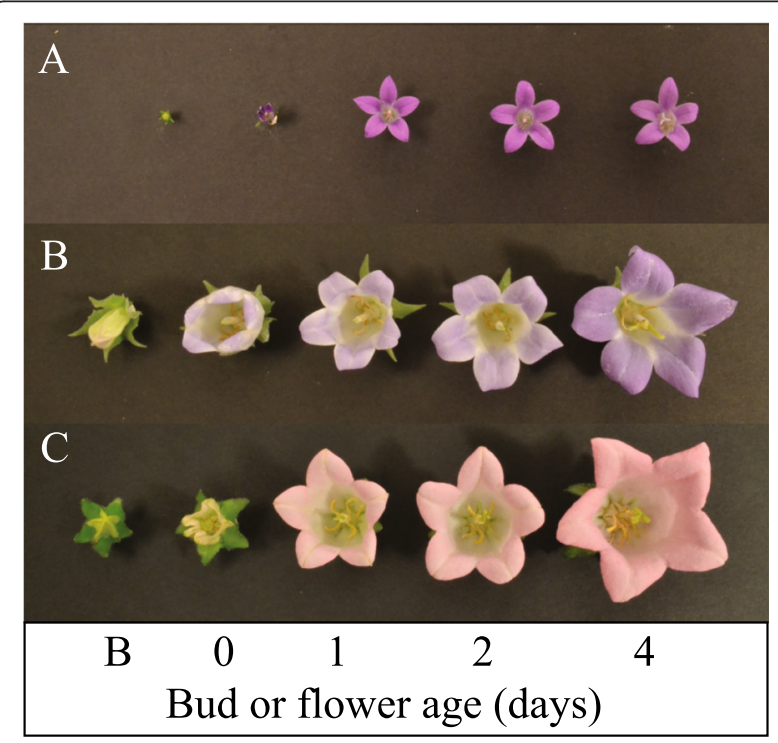

Fig. 3 Developmental stages of Campanula flowers. Developmental stages are unripe bud (B), day 0 (one day before flowering) and 1, 2 and 4-day old flowers of a Campanula portenschlagiana (Cp), b C. formanekiana and c C. medium $(\mathrm{Cm})$ 


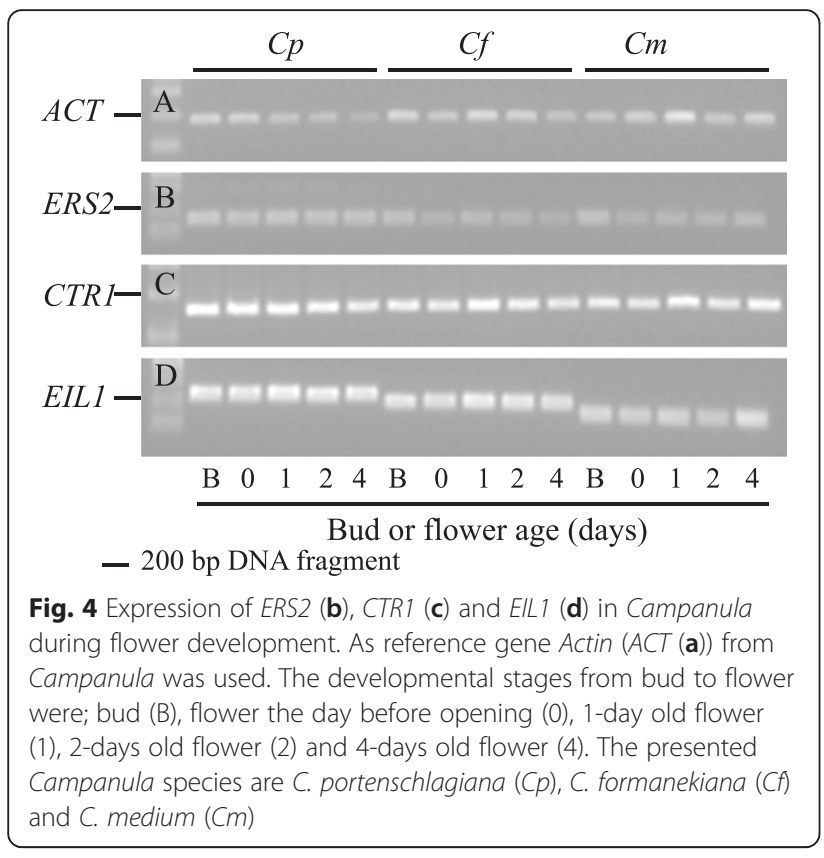

(Fig. 2). The $7 \mathrm{bp}$ deletion in Cmeil2 was verified from independent gDNA extractions (data not shown). At the nucleotide level CfEIL2 and Cmeil2 shared $96 \%$ identity to each other and $76 \%$ identity to CfEIL1 and CmEIL1 respectively (Table 1). PCR reactions specific for EIL2 using $C p$ gDNA or cDNA did not amplify a product.

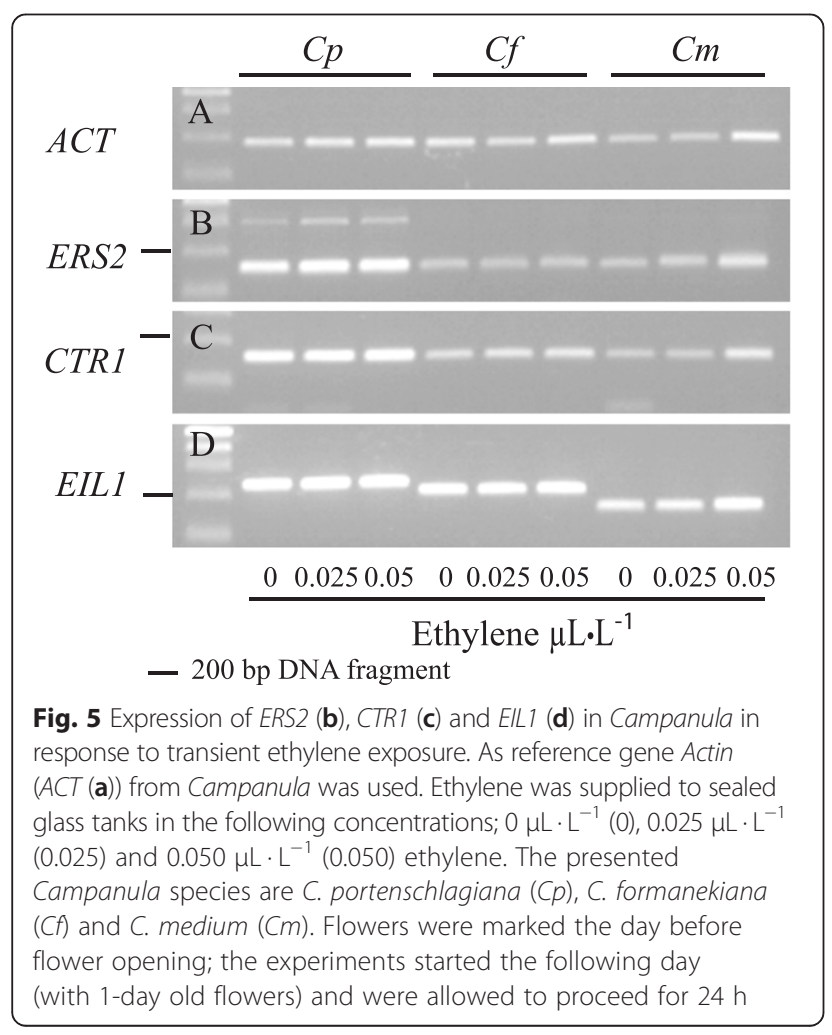

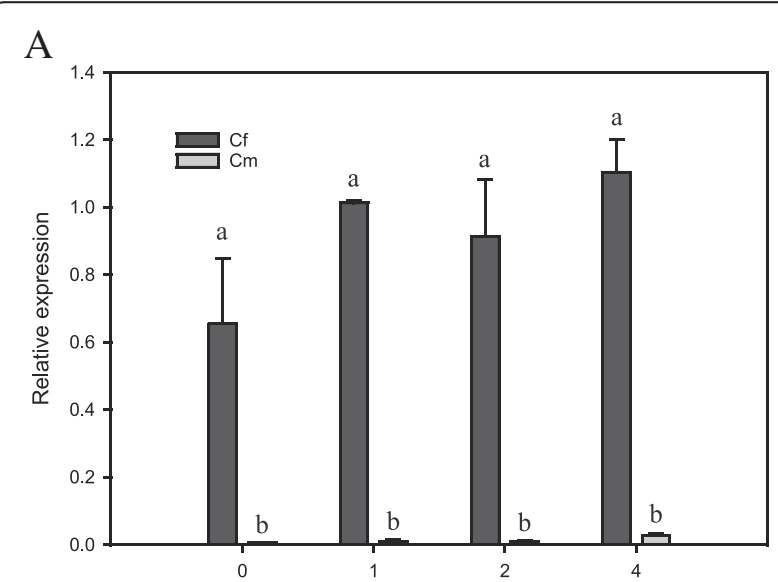

B

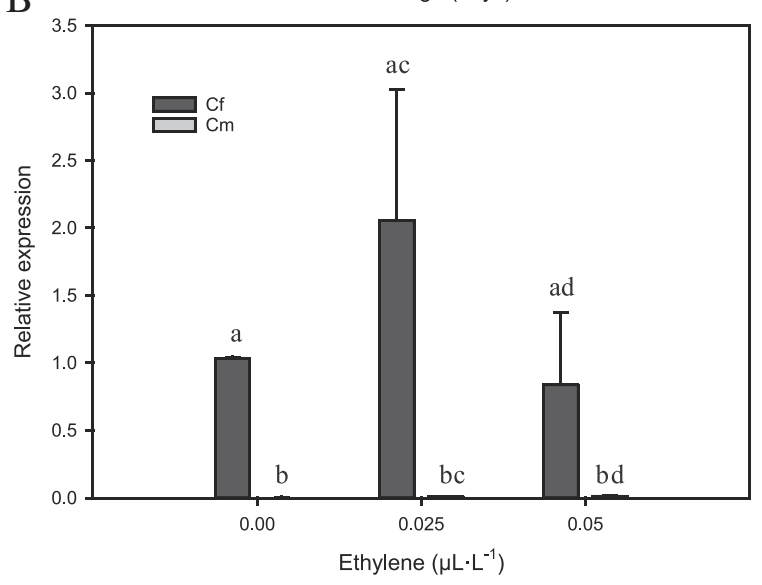

$\mathrm{C}$

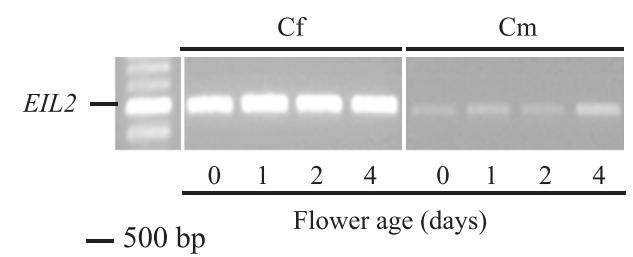

$\mathrm{D}$

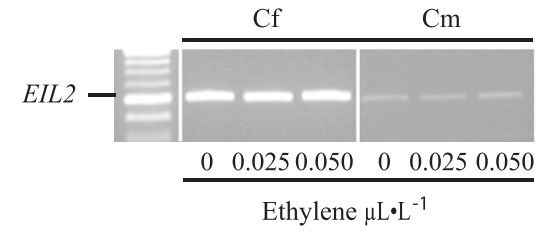

Fig. 6 Expression of ElL2 in large flowered Campanula during flower development and following ethylene exposure. Campanula species are $C$. formanekiana (Cf) and C. medium ( $\mathrm{Cm}$ ). In a, c the floral developmental stages were; day before opening (0), 1-day old flower (1), 2-days old flower (2) and 4-days old flower (4). In $\mathbf{b}, \mathbf{d}$ ethylene was supplied to sealed glass tanks at the following concentrations; $0.00 \mu \mathrm{L} \cdot \mathrm{L}^{-1}(0), 0.025 \mu \mathrm{L} \cdot \mathrm{L}^{-1}$ (0.025) and $0.050 \mu \mathrm{L} \cdot \mathrm{L}^{-1}(0.050)$ ethylene. Results from RT-qPCR are presented as relative expressions in (a) and (b). The corresponding results of EIL2 RT-PCR loaded on agarose gels are presented in (c) and (d). The values of 1-day flowers and $0 \mu \mathrm{L} \cdot \mathrm{L}^{-1}$ ethylene were set to the value 1 in (a) and (b), respectively. As reference gene Actin (ACT) from Campanula was used, these RT-PCR results are presented in Figs. 4a and 5a. RT-qPCR data were normalized to transcripts of the same ACT. Data are means \pm SE. Values with same letters are not significantly different $(P>0.05)$ 


\section{Expression analysis of putative ERS2, CTR1, EIL1 and EIL2 homologues}

To address the transcriptional regulation of the ethylene signal transduction pathway in Campanula, flower tissues were harvested at five developmental stages (from bud to fully expanded flower on day 4, Fig. 3). Transcripts of putative ERS2, CTR1 and EIL1 were expressed constitutively during flower development (Fig. 4). To determine whether Campanula ERS2, CTR1 or EIL1 were responsive to ethylene, transcriptional analysis were performed in young (1-day old) flowers exposed to $0.025 \mu \mathrm{L} \cdot \mathrm{L}^{-1}$ or $0.050 \mu \mathrm{L} \cdot \mathrm{L}^{-1}$ ethylene for $24 \mathrm{~h}$. However, neither ERS2, CTR1 nor EIL1 transcripts were responsive to the applied ethylene treatments (Fig. 5).

Expression patterns of CfEIL2 and Cmeil2 transcripts were analyzed by classic RT-PCR and RT-qPCR. CfEIL2 transcripts showed expression pattern and levels similar to those of CfEIL1 throughout flower development and in response to $0.025 \mu \mathrm{L} \cdot \mathrm{L}^{-1}$ and $0.050 \mu \mathrm{L} \cdot \mathrm{L}^{-1}$ ethylene for $24 \mathrm{~h}$ (Fig. 6). In contrast, Cmeil2 was detectable in trace amounts when analysed by RT-PCR. Quantitative analysis by RT-qPCR showed consistently very low levels of Cmeil2 through flower development and no transcriptional response to ethylene. Expression levels of CfEIL2 and Cmeil2 differed by more than 100-fold in young flowers (day 0, day 1 ) whereas the same comparison in old flowers (day 4) yielded only 40-fold changes. The variation in fold change was primarily due to nonsignificant increases in Cmeil2 transcript levels. Expression levels of CfEIL2 and Cmeil2 in response to ethylene were not found to be significantly different due to the large variation in CfEIL2 expression levels (Fig. 6b).

\section{The eil2 frameshift mutation is unique for $C$. medium}

Alignment of the putative EIL2 protein fragment from Campanula with EIL protein sequences from other

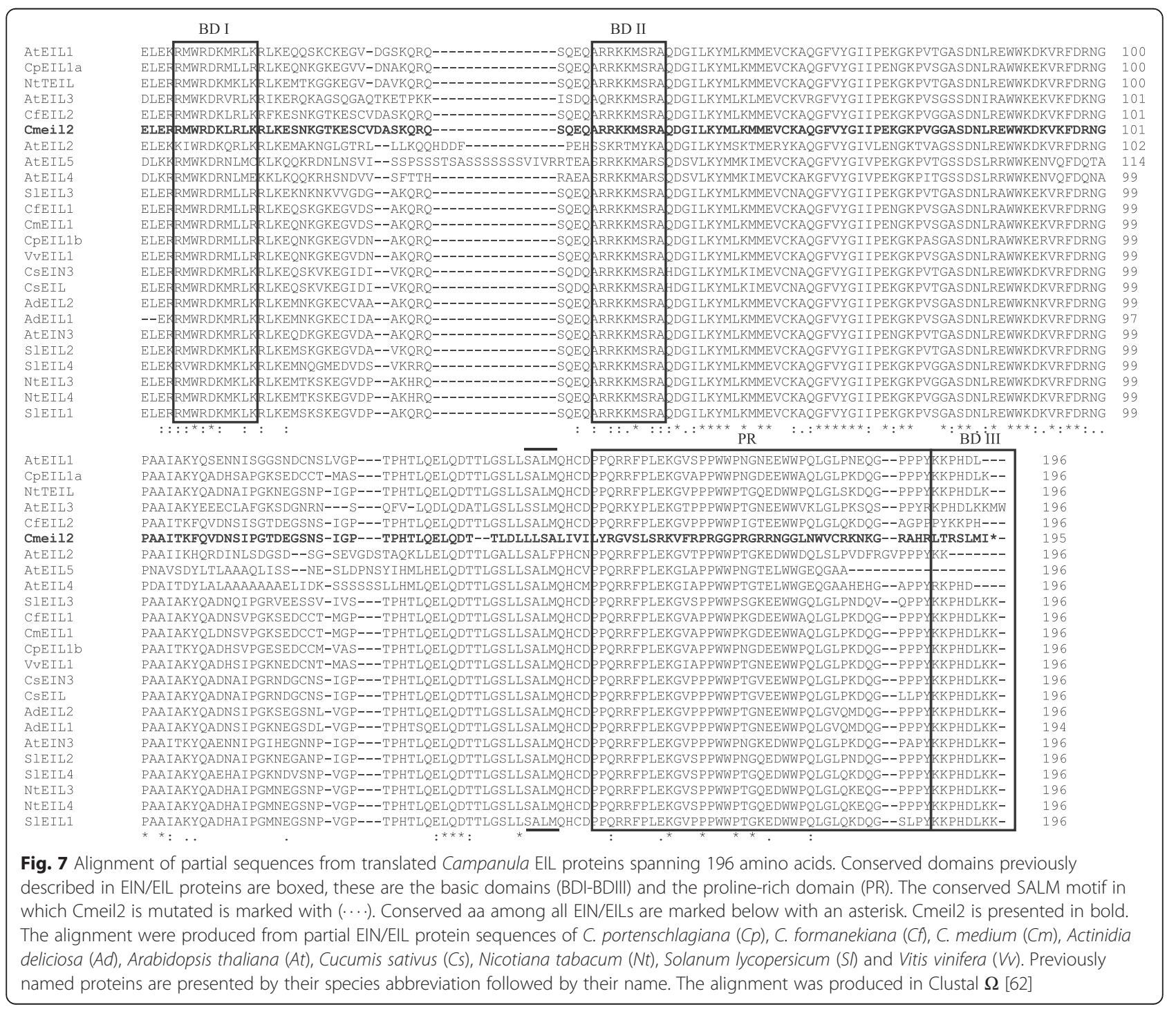


plants confirmed the presence of three conserved domains found in other EILs. These domains comprise the two basic amino acids binding domains (BD I and BD II) and the proline-rich region (PR) (Fig. 7). At the protein level the putative EILs from Campanula were closely related to each other when compared to other EILs except for Cmeil2. Cmeil2 showed high homology to other EILs until the position of the frameshift. The sequence following downstream of the frameshift was only observed in $\mathrm{Cm}$ and did not show any homology to previously reported EIL proteins. Omission of the deletion from the Cmeil2 reading frame resulted in a protein that perfectly aligned with other EIL2 proteins (data not shown). Phylogenetic analysis using other plant EILs indicated a close relation among Campanula EILs and a clear phylogenetic separation of Campanula EIL1 and EIL2 proteins (Fig. 8). Some branch points in the phylogenetic analysis yielded low bootstrap values due to the size of the aligned fragment (200 amino acids) and the high identity among all the EILs (Fig. 8).

\section{Characterization of eil2 in Campanula species and cultivars}

To elucidate the natural occurrence of eil2 in Campanula, close relatives to $C$. medium were identified as $C$. hofmannii, C. alpina, C. alpestris and Edraianthus graminifolius and C. incurva as close relative to C. formanekiana [32]. As the Cmeil2 mutation disrupts an NlaIII restriction site in EIL2 a simple screen for the presence of the mutation was developed (Fig. 9). EIL2 PCR products digested with NlaIII resulted in either two or three DNA fragments depending on the presence or lack of the eil2 mutation, respectively. Results obtained via NlaIII digests were verified by sequencing. Interestingly, eil2 was found to be specific for $\mathrm{Cm}$ and did not occur in related Campanula species (Fig. 9a). Intraspecific NlaIII restriction analysis among $\mathrm{Cm}$ cultivars confirmed the occurrence of eil2 regardless of cultivar origin (Fig. 9b). Thus the reported frameshift mutation in Cmeil2 is specific for $\mathrm{Cm}$ and occurs in all tested $\mathrm{Cm}$ both among non domesticated and domesticated cultivars.

\section{Characterization of eil2 in hybrids of $\mathrm{Cf} \times \mathrm{Cm}$}

As $C m$ is homozygote for eil2 whereas $C f$ is homozygote for EIL2 the performance of eil2 in heterozygote plants were evaluated by ethylene exposure tests in $C$. formanekiana $\times C$. medium hybrids. The presence of eil2 in $\mathrm{Cf} \times \mathrm{Cm}$ hybrids (A-E) was verified using the NlaIII screening system (Fig. 10). Young flowers were exposed to high ethylene concentrations of $5.0 \mu \mathrm{l} \cdot \mathrm{L}^{-1}$ for $72 \mathrm{~h}$ and flower responses were scored in categories of no response, signs of senescence and complete senescence (Table 2). Interestingly, four heterozygote $\mathrm{Cf} \times \mathrm{Cm}$

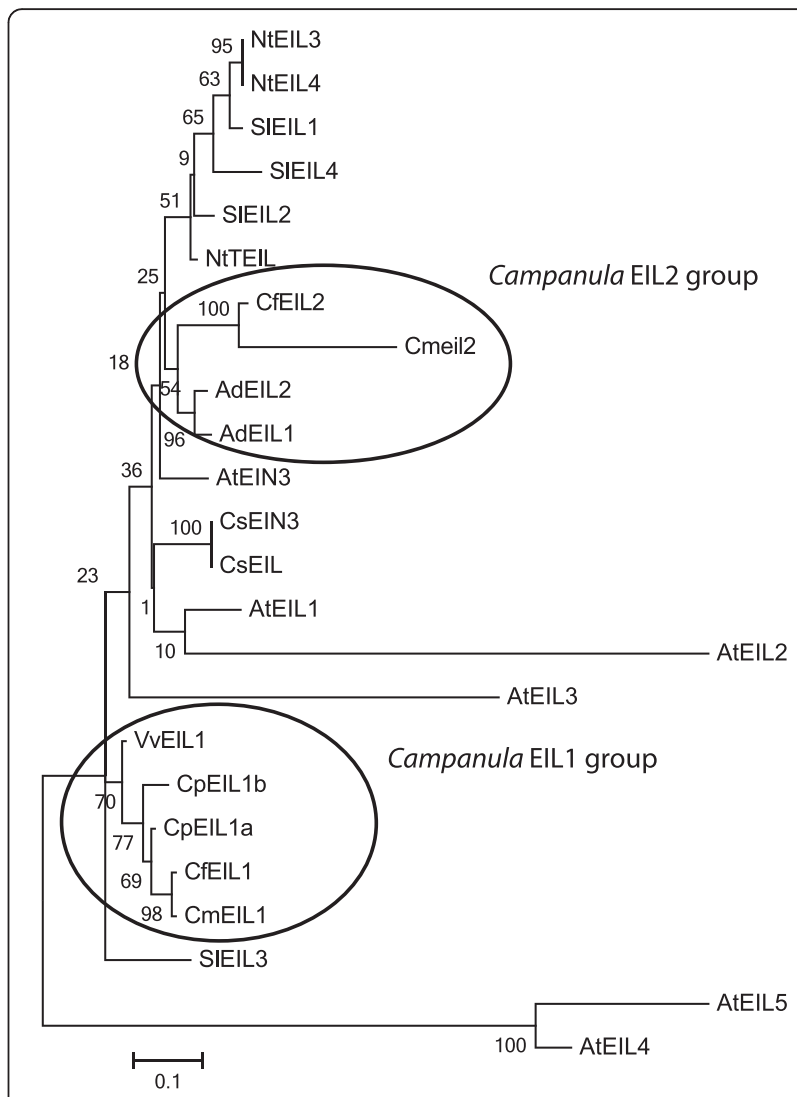

Fig. 8 Phylogenetic tree of ElLs in plants. The phylogenetic tree was produced from partial EIN/EIL protein sequences spanning 196 amino acids. The clustering in two groups of EIL1 and EIL2 proteins from Campanula are highlighted in ellipses. Low bootstrap values in some parts of the phylogenetic analysis are due to the size of the partial EIN/EIL proteins (196 aa) and the high level of aa identity among them. The phylogenetic tree were produced from partial EIN/EIL protein sequences of $C$. portenschlagiana $(C p), C$.

formanekiana (Cf), C. medium (Cm), Actinidia deliciosa (Ad), Arabidopsis thaliana (At), Cucumis sativus (Cs), Nicotiana tabacum (Nt), Solanum lycopersicum (S) and Vitis vinifera (VV). Previously named proteins are presented by their species abbreviation followed by their name. The phylogenetic analysis were produced from MEGA version 6 [63]

hybrids showed phenotypes indistinguishable from that of $C f$ with $87-100 \%$ of flowers showing complete senescence in response to ethylene. A single hybrid (E) exhibited an intermediate phenotype with $57 \%$ senesced flowers. In contrast, two $\mathrm{Cm}$ breeding lines maintained flower longevity longer and only $0-5 \%$ of flowers senesced as a result of $72 \mathrm{~h}$ of $5.0 \mu \mathrm{l} \cdot \mathrm{L}^{-1}$ ethylene exposure.

\section{Discussion}

\section{Ethylene sensitivity in Campanula}

Ethylene sensitivity of flowers is a recurring problem affecting breeders, producers and costumers of ornamental 


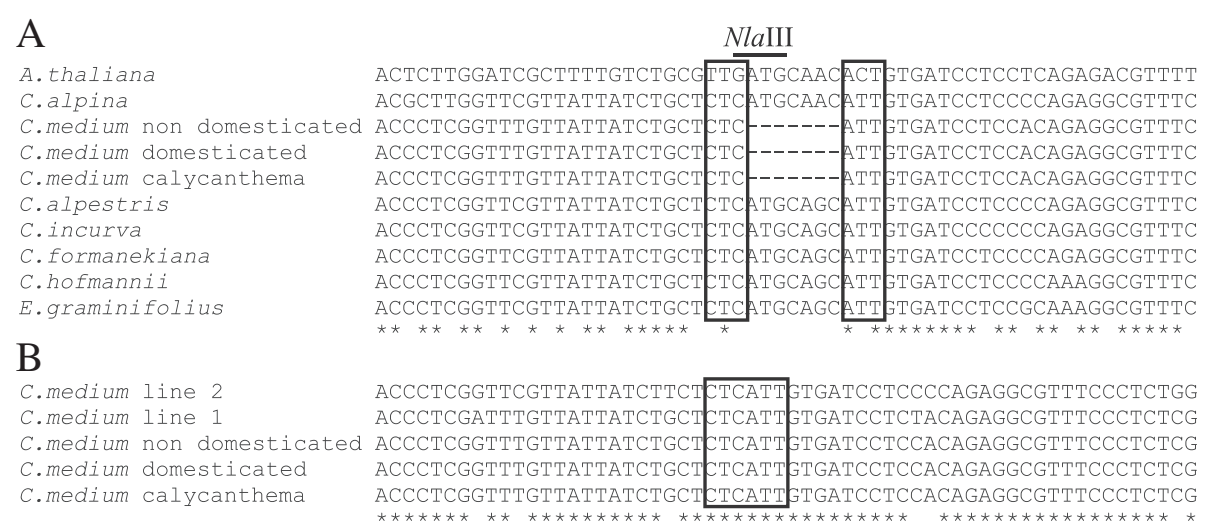

Fig. 9 Alignment of genomic EIL2 DNA sequences. The aligned area presented is centered on the seven bp deletion in C. medium (represented with -). Nucleotides bordering the mutation are boxed. Conserved nucleotides are marked with asterisk. a Ell2 from six Campanula species, three C. medium cultivars, Edraianthus graminifolius, and Arabidopsis EIN3. The restriction site of Nlall found in Ell2 Campanula sequences not having the mutation is marked with bold line $\mathbf{b}$ eil2 from three C. medium cultivars and two PKM breeding lines (line 1 (Sweet Mee ${ }^{\oplus}$ ) and line 2)

plants [17]. Thus characterisation of physiological and molecular variations in economically important Campanula species are much needed. In the present study, ethylene sensitivity among C. portenschlagiana, C. formanekiana and $C$. medium were found to depend on physiological and genetic factors. Ethylene sensitivity in flowers were dependent on genotype as $C p$ was highly sensitive, $C f$ had an intermediate level of sensitivity and $\mathrm{Cm}$ was found to be insensitive to high concentrations of ethylene (Fig. 1, 10). Labelling of flower developmental stage showed a link between flower age and ethylene sensitivity, where a higher proportion of flowers senesced among the older flowers. Only old flowers of $C p$ were

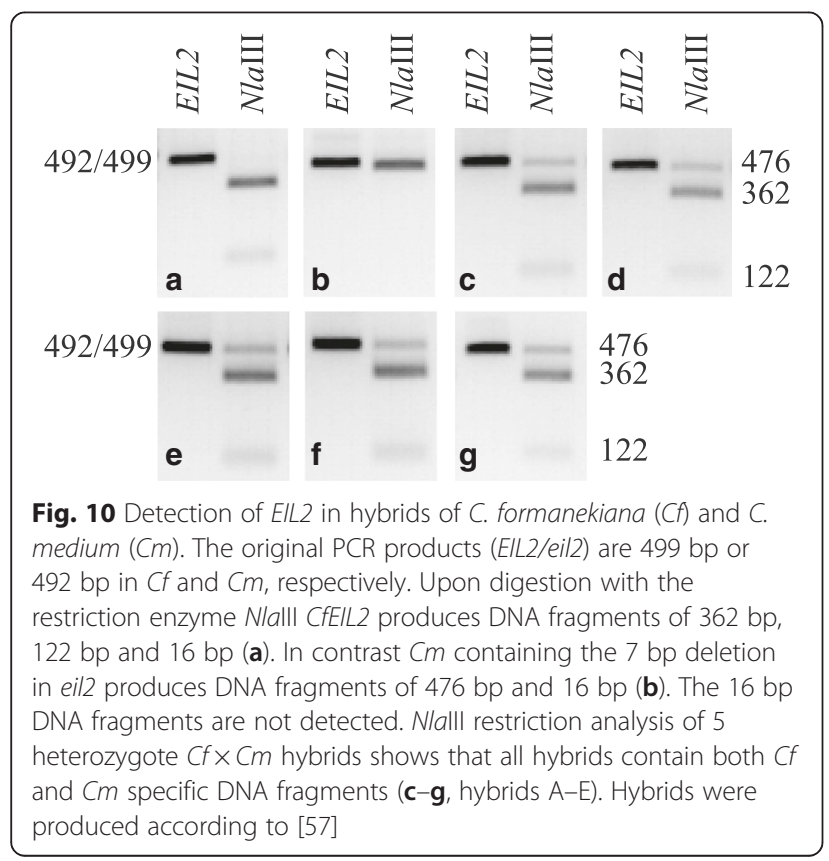

Table 2 Flower responses to ethylene exposure in C. medium, C. formanekiana and C. formanekiana $\times$ C. medium hybrids. Plants were exposed to concentrations of 0 or $5 \mu \mathrm{l} \cdot \mathrm{L}^{-1}$ ethylene for $72 \mathrm{~h}$. Flower responses were grouped in three categories (no senescence, signs of senescence and complete senescence). Data are in \% and presented as means \pm SE $(n=2$, except $\mathrm{Cm}$ line $1 ; n=4$ ). Values with same letters within treatments in same response are not significantly different $(P>0.05)$

\begin{tabular}{|c|c|c|c|}
\hline Species/hybrid & No senescence & $\begin{array}{l}\text { Signs of } \\
\text { senescence }\end{array}$ & $\begin{array}{l}\text { Complete } \\
\text { senescence }\end{array}$ \\
\hline & $0 \mu \mathrm{l} \cdot \mathrm{L}^{-1}$ ethylene, $72 \mathrm{~h}$ & & \\
\hline C. formanekiana & $87 \pm 4.7^{a}$ & $13 \pm 4.7^{\mathrm{d}}$ & $0.0 \pm 0.0^{\mathrm{a}}$ \\
\hline C. medium line $1^{1}$ & $3.3 \pm 2.9^{d}$ & $97 \pm 2.9^{a}$ & $0.0 \pm 0.0^{\mathrm{a}}$ \\
\hline C. medium line $2^{1}$ & $53 \pm 19^{a b}$ & $47 \pm 19^{c d}$ & $0.0 \pm 0.0^{a}$ \\
\hline Hybrid A & $53 \pm 0.0^{a b}$ & $47 \pm 0.0^{\mathrm{cd}}$ & $0.0 \pm 0.0^{a}$ \\
\hline Hybrid B & $17 \pm 2.4^{\mathrm{bcd}}$ & $83 \pm 2.4^{a b}$ & $0.0 \pm 0.0^{a}$ \\
\hline Hybrid C & $40 \pm 4.7^{\mathrm{bc}}$ & $60 \pm 4.7^{\mathrm{bc}}$ & $0.0 \pm 0.0^{a}$ \\
\hline Hybrid D & $10 \pm 7.1^{\mathrm{cd}}$ & $90 \pm 7.1 \mathrm{ab}$ & $0.0 \pm 0.0^{a}$ \\
\hline \multirow[t]{2}{*}{ Hybrid E } & $3.3 \pm 2.4^{\mathrm{cd}}$ & $97 \pm 2.4^{a b}$ & $0.0 \pm 0.0^{a}$ \\
\hline & $5 \mu \mathrm{l} \cdot \mathrm{L}^{-1}$ ethylene, $72 \mathrm{~h}$ & & \\
\hline C. formanekiana & $0.0 \pm 0.0^{\mathrm{a}}$ & $0.0 \pm 0.0^{c}$ & $100 \pm 0.0^{a}$ \\
\hline C. medium line $1^{1}$ & $0.0 \pm 0.0^{a}$ & $95 \pm 4.3^{a}$ & $5.0 \pm 4.3^{c}$ \\
\hline C. medium line $2^{1}$ & $0.0 \pm 0.0^{a}$ & $100 \pm 0.0^{a}$ & $0.0 \pm 0.0^{c}$ \\
\hline Hybrid A & $0.0 \pm 0.0^{a}$ & $13 \pm 9.4^{c}$ & $87 \pm 9.4^{a}$ \\
\hline Hybrid B & $0.0 \pm 0.0^{\mathrm{a}}$ & $3.3 \pm 2.4^{c}$ & $97 \pm 2.4^{\mathrm{a}}$ \\
\hline Hybrid C & $0.0 \pm 0.0^{\mathrm{a}}$ & $0.0 \pm 0.0^{c}$ & $100 \pm 0.0^{a}$ \\
\hline Hybrid D & $0.0 \pm 0.0^{a}$ & $10 \pm 7.1^{c}$ & $90 \pm 7.1^{\mathrm{a}}$ \\
\hline Hybrid E & $0.0 \pm 0.0^{a}$ & $43 \pm 7.1^{b}$ & $57 \pm 7.1^{b}$ \\
\hline
\end{tabular}

${ }^{1} \mathrm{C}$. medium breeding lines 1 (Sweet Mee ${ }^{\oplus}$ ) and 2 
sensitive to low amounts of $0.05 \mu \mathrm{L} \cdot \mathrm{L}^{-1}$ ethylene, whereas all flowers of $C p$ were sensitive to $0.1 \mu \mathrm{L} \cdot \mathrm{L}^{-1}$ ethylene. Doubling the ethylene concentration resulted insignificant increase in senesced $C f$ flowers from 26 to $100 \%$ and also in complete loss of flower longevity in young $C f$ flowers (Fig. 1). In the same experimental settings all flowers of $\mathrm{Cm}$ were insensitive to ethylene. A similar correlation between flower age and ethylene sensitivity has been observed in Pelargonium peltatum [33]. This age dependent increase in sensitivity may also be connected to pollination as some plant species induce flower senescence upon pollination [34-36].

Whereas $C f$ flowers are ethylene sensitive in a concentration dependent manner (Fig. 1e, Table 2) not even a 50 -fold increase in ethylene concentration reduced flower longevity in $\mathrm{Cm}$. This indicates that ethylene insensitivity of $\mathrm{Cm}$ is independent of ethylene concentrations (Fig. 1f, Table 2).

\section{Constitutive expression of ERS2 and CTR1 in flowers}

Expression of ERS2 was found to be constitutive in Campanula during floral development and transcripts in young flowers were also unresponsive to low concentrations of ethylene (Figs. 4b and 5b). In both Arabidopsis and roses ethylene receptors are encoded by five genes [6, 37-39], some of which exhibit differential expression in response to exogenous ethylene and are regulated during flower development tissues [40, 41]. Also, exogenously applied ethylene does not affect levels of $D i$ anthus caryophyllus ERS2 in petals but this gene is regulated by flower development [42]. Collectively, results obtained in other plants indicate that ethylene receptor families comprise multiple members. The genome of $C p$ was found to contain two homologs of ERS receptors whereas only one gene/transcript was identified in $C f$ and $\mathrm{Cm}$. As gDNA was also used as template in the cloning reactions mRNA levels in flower tissues should not be the determining factor. Thus all three Campanula species likely encode additional ethylene receptors which were not identified here due to primer specificities.

Similarly as for ERS2, all Campanula CTR1 transcripts were constitutively expressed during flower development and did not respond to application of exogenous ethylene (Figs. $4 \mathrm{c}$ and $5 \mathrm{c}$ ). The same pattern was observed in roses where RhCTR1 and RhCTR2 were constitutively expressed throughout flower development; however both RhCTR transcript levels increased in response to ethylene [43]. In some plant species the genomic structure of CTR1 is highly complex. Banana and tomato CTR1 exist in a 15 exon 14 intron structure yielding complete ORFs of 11.5 and $12 \mathrm{~kb}$, respectively [44, 45]. Even with a long elongation time in PCR reactions we were not able to identify the full-length sequence of Campanula CTR1. However small polymorphisms detected in the partial
$C p, C f$ and $C m$ CTR1 transcripts indicate that these plants may be heterozygote in the CTR1 locus or that an additional copy of CTR1 exists. Two and four CTR homologs have been identified in roses and tomato, respectively $[43,46]$. Hence an additional CTR1 in Campanula is not unlikely.

\section{Occurrence and expression of ElLs in Campanula}

The EIN3/EIL family encodes transcription factors mediating the initialization of the physiological ethylene response [13, 47]. In the three Campanula species investigated here approximately $600 \mathrm{bp}$ of a flower expressed EIL homologue were identified, EIL1. All EIL1 transcripts were consistently expressed through flower development and did not respond to applied ethylene (Figs. $4 \mathrm{~d}$ and $5 \mathrm{~d}$ ). In the small flowered $C p$ two close homologs of EIL1 were identified by sequencing as EIL1a and EIL1b, however the two could not be separated during expression analysis. In contrast, the two large flowered Campanula ( $\mathrm{Cf}$ and $\mathrm{Cm}$ ) both contained the ORF of EIL2, a gene not detected in Cp. CfEIL2 gene expression was like CfEIL1 constitutive throughout flower development and nonresponsive to exogenous ethylene (Fig. 6c, d). In $\mathrm{Cm}$, eil2 was not expressed due to the deletion of $7 \mathrm{bp}$ in the ORF (Figs. 2 and 6). Translational analysis of the partial Cmeil2 protein indicated that the 7 bp deletion would introduce a frameshift prior to what should have been the proline rich domain in Cmeil2 (Fig. 7). On nucleotide level CfEIL2 and Cmeil2 share $96 \%$ identity (Table 1), showing that they are close homologs. The close homology among CfEIL2 and Cmeil2 was supported by phylogenetic analysis (Fig. 8). Translation of the putative Cmeil2 indicate that the frameshift mutation in eil2 disrupts the putative major DNA binding domain in EIL2 in front of the proline rich region and simultaneously introduces a stop codon 50 amino acids further downstream in the eil2 protein sequence. Hence, if translated the protein would be truncated to approximately $40 \%$ of the expected size when compared to AtEIN3 (Fig. 7). The position and functionality of EIL DNA binding domains have been characterised in Arabidopsis EIL3 and in cucumber EIN3 [48, 49].

Whether the promoters of CfEIL2 and Cmeil2 share the same specificity remains to be shown, however Cmeil2 may have been expressed in flowers at one point as traces of the transcript was observed in RT-PCR and in RT-qPCR (Fig. 6). Finally, additional EIL homologs may be present in Campanula as 4-6 homologs have been identified in Arabidopsis, tomato and tobacco [13, 50-52].

Previous studies of EIN3/EIL homologs have shown constitutive expression in Paeonia, however in Dianthus caryopyllus DcEIL1/2 and DcEIL3 transcripts in petals and styles increased rapidly after ethylene treatment of 
flowers and then gradually declined [53,54]. The constitutive expressions of ERS2, CTR1 and EILs in the ethylene signal transduction pathway in Campanula indicate that flowers are capable of a fast physiological response in the presence of ethylene. This correlate well with earlier results where Campanula has been described as an ethylene sensitive species [20]. Furthermore, the lack of transcriptional response to ethylene exposure could be a combination of regulatory steps on the protein level $[55,56]$.

\section{The Cmeil2 phenotype was inherited as a recessive trait}

In the present study, the eil2 frameshift mutation was identified not only in Danish domesticated $\mathrm{Cm}$ but also in non domesticated specimens of $\mathrm{Cm}$ and in the closely related C. medium var. calycanthema (Fig. 9). This suggests that the eil2 frameshift must have occurred in an earlier ancestor of $\mathrm{Cm}$. None of the closely related Campanula species C. alpina, C. alpestris, C. hofmannii or $E$. graminifolius contained eil2 (Fig. 9). In hybrids of $C f \times$ $\mathrm{Cm}$, heterozygote eil2 resulted in very similar ethylene responses as observed in $C f$ as only one of five hybrids showed an intermediate phenotype shifted towards increased ethylene insensitivity when compared to $C f$ (Table 2). This indicated that the eil2 phenotype was restored by the presence of a wild type EIL2 and was inherited as a recessive trait. Homozygote eil2 in $C f$ could not be obtained via crossings as both male and female parts of $C f \times C m$ hybrids were sterile. Results obtained here are the first to describe the effects of an ein3/eil mutation in flowers. Also, no reports exist of approaches where EIN3/EIL genes have been knocked out or silenced via gene modification. Therefore the eil2 phenotype described in $\mathrm{Cm}$ cannot be directly compared to related phenotypes in flowers of other plant species. In Arabidopsis, the closest homolog to Campanula EIL2 is EIN3 (AtEIN3). In Arabidopsis, ein3 mutants are well characterised and they too are inherited in a recessive manner [13]. Also phenotypes in ein3 or eil mutants in Arabidopsis are only described in seedlings or mature rosettes. To our knowledge ethylene sensitivity and floral development has not been described in Arabidopsis ein 3 or eil mutants. However, in support of our results are data from tomato where expression of LeEIL1, LeEIL2 or LeEIL3 antisense transcripts results in ethylene insensitive buds [51]. Collectively, this study is the first to correlate ethylene insensitivity in flowers to an ein/eil mutant phenotype.

Future approaches to achieve ethylene insensitive plants Previous studies have indicated that there may be specific functions for the individual EILs. Thus to alter the physiological response of flowers to ethylene, the right ortholog in each plant species has to be identified. In the framework of this study, the Cmeil2 frameshift mutation could potentially be transferred to EIL2 homologs of related species by conventional crossing or the deletion could be introduced by wide hybridisation among related species, assisted by embryo rescue techniques when necessary [57].

The frameshift in Cmeil2 is positioned in a highly conserved region, and it therefore holds potential for molecular breeding towards ethylene insensitive plants. However, the identification of the full genomic sequence in $C m$ and $C f$ and the full sequence of the translated gene product in $C f$ are essential steps in this process. Ultimately, we propose that the identified 7 bp deletion in Cmeil2 may be used to confer ethylene insensitivity to other plant species. This may be feasible via targeted mutagenesis techniques utilizing ZNF, TALENs [58] or CRISPR/Cas9 [59]. As a result, ethylene insensitivity may be transferred from $\mathrm{Cm}$ to other important climacteric ornamentals e.g., roses, Petunia, carnations, or even to edible climacteric crops such as broccoli and tomato.

\section{Conclusions}

We characterised the physiological and molecular responses among three Campanula species to exogenous ethylene. Key genes in the ethylene signal transduction pathway ERS, CTR and EIL1 were found to be constitutively expressed in Campanula and unresponsive to exogenous ethylene. However, EIL2 was found to be specific for the large flowered species C. formanekiana and $C$. medium, but was not expressed in $\mathrm{Cm}$ due to a 7 nucleotide frameshift in the coding region of Cmeil2. The natural mutation identified here in Cmeil2 correlates with the observed ethylene insensitivity in this species. This finding holds great potential for future breeding strategies towards ethylene insensitive plants.

\section{Methods}

Plant materials and growth conditions

Campanula portenschlagiana Schultes 'Blue GET MEE' $(C p)$, Campanula formanekiana Degen \& Doefler 'Blue MARY MEE ${ }^{\text {' }}(C f)$, Campanula medium L. 'Sweet MEE' $(\mathrm{Cm}), \mathrm{C}$. medium breeding line 2 and $C$. medium var. calycanthema were received from the nursery Gartneriet PKM A/S (Odense, Denmark) in a developmental stage with young flower buds. Hybrids of C. formanekiana $\times$ C. medium (A-E) were produced by ovule culture [57] or at Gartneriet PKM A/S. Upon arrival, plants were transferred to a greenhouse with $18{ }^{\circ} \mathrm{C}$ day $/ 15^{\circ} \mathrm{C}$ night and a 16 -h photoperiod of natural light. Seeds of the non domesticated C. medium were provided by the Alpine Staudengärtnerei (Leisning, Germany). Seeds of C. alpina, C. alpestris, C. hofmannii, C. incurva and Edraianthus graminifolius were obtained from B \& T World Seeds (Aigues-Vives, France). 
Identification of putative ERS2, CTR1 and EIL genes

Based on the NCBI GenBank [60] sequence from Campanula carpatica (GenBank: AF413669) intron spanning primers were designed to amplify partial fragments of ERS2. ERS2 PCR on gDNA produced two ERS2 products in $C p$ and one ERS2 genomic fragment in $C f$ and $\mathrm{Cm}$. In $C p$, The two $C p E R S 2$ products were derived from two genes containing different intron sizes but coding for very similar transcripts (CpERS2a and $C p E R S 2 b$, Additional file 3). A partial CTR1 was produced using degenerate primers aligning to conserved areas among Musa acuminata, Solanum lycopersicon, Arabidopsis thaliana and Rosa hybrida CTR1 sequences (GenBank:JF430422, GenBank:AF096250, GenBank:NM_1804 29, and GenBank:AY032953). Sequencing showed some polymorphisms in CTR1 of $C p, C f$ and $C m$. This could indicate that more than one copy of CTR 1 exist in Campanula. Partial EIL genes cloned via degenerate primers produced from Malus x domestica and Solanum lycopersicon EIL sequences (GenBank:GU732486 and GenBank:NM_001247617). Campanula ACT was amplified using degenerate primers, sequenced and from this sequence specific primers were designed for expression analyses. Primers and PCR product sizes are presented in Additional file 3.

Genomic DNA from $C p, C f$, and $C m$ was isolated from flowers with DNeasy Plant Mini Kit (Qiagen) using $300 \mathrm{mg}$ of plant material following manufacturer's recommendations. PCR reactions used 100-250 ng gDNA, $2 \%(\mathrm{v} / \mathrm{v})$ DMSO and polymerase LaTaq (Takara Bio Inc.) as manufacturer recommends. Reactions followed the program; 4 min $94{ }^{\circ} \mathrm{C}, 33-35$ cycles of $\left[30 \mathrm{~s} 94{ }^{\circ} \mathrm{C}, 1 \mathrm{~min}\right.$ $\left.60{ }^{\circ} \mathrm{C}, 1 \mathrm{~min} 72{ }^{\circ} \mathrm{C}\right]$ and a final 7 min elongation step at $72{ }^{\circ} \mathrm{C}$ in a MyCycler (Biorad). Cloning of PCR-products was via TOPO TA Cloning ${ }^{\circ}$ kit (Life Technologies Corp, Invitrogen) as recommended by manufacturer. Plasmids were purified by QIAprep Spin Miniprep kit (Qiagen) and sequenced by Eurofins MWG Operon. EIL2 PCR products were purified with QIAquick PCR purification Kit (Qiagen) and restriction analyses using NlaIII were done as supplier recommends (New England Biolabs).

\section{Ethylene exposure experiments}

To monitor flower development, individual buds were labelled one day before flower opening. This stage was termed day 0 . In the following days newly opened flowers (day 1 ) and 4 days old flowers (day 4) were identified, tagged and used in subsequent experiments. This allowed two morphologically different stages to be monitored simultaneously throughout the ethylene exposure experiments. Ethylene exposure were conducted in a climate chamber in glass tanks with postharvest growth conditions; $20{ }^{\circ} \mathrm{C}$ day $/ 18{ }^{\circ} \mathrm{C}$ night, 16 -h photoperiod at
10-12 $\mu \mathrm{mol} \mathrm{m}{ }^{-2} \cdot \mathrm{s}^{-1}$ provided by cool-white fluorescent tubes (Philips Master TL-D-36 W/830). Each glass tank had a volume of $128 \mathrm{~L}$ and contained three plants. Flower labeling resulted in each glass tank containing three plants with a total of 15 labelled flowers for each developmental stage (day 1 and day 4). Except for $\mathrm{Cm}$ where 8-13 labeled flowers pr. growth stage were used. Ethylene concentrations of $0 \mu \mathrm{L} \cdot \mathrm{L}^{-1}, 0.05 \mu \mathrm{L} \cdot \mathrm{L}^{-1}$ or $0.1 \mu \mathrm{L} \cdot \mathrm{L}^{-1}$ were obtained by injection of gaseous ethylene (Mikrolab Aarhus A/S) into sealed glass tanks. Flowers were monitored, tanks ventilated and ethylene reinjected every $24 \mathrm{~h}$. For Fig. 1 a senescent flower was defined as a flower showing twisted or closed corolla or wilted. For Table 2, ethylene sensitivity of $C f \times C m$ hybrid flowers were classified in three categories; no symptoms, signs of senescence (partial wilting and discoloration of corolla) and complete senescence (complete wilting and full discoloration of corolla). The latter experiments were done in glass tanks with $5 \mu \mathrm{l} \cdot \mathrm{L}^{-1}$ ethylene for 72 h. $C p$ and $C f$ experiments were repeated twice whereas $\mathrm{Cm}$ experiments were in three replicates.

Gene expression analyses were done at developmental stages: bud, day 0 (one day before flowering), day 1 , day 2 and day 4 (Fig. 3). Plants were subjected to low ethylene concentrations of $0.025 \mu \mathrm{L} \cdot \mathrm{L}^{-1}$ and $0.050 \mu \mathrm{L} \cdot \mathrm{L}^{-1}$ ethylene for $24 \mathrm{~h}$. Each tank contained three plants with labeled 1-day flowers. Flowers from each tank were pooled, harvested in liquid nitrogen, grinded and used for RNA extraction. Each experiment was performed in three replicates.

\section{RNA extraction, CDNA synthesis and expression analysis}

RNA was extracted using RNeasy Plant Mini kit (Qiagen) with the following change to manufacturer's protocol: Cell lysis were done using RLT buffer with $0.01 \% \beta$ mercaptoethanol (v/v) for 1 min at $56{ }^{\circ} \mathrm{C}$. RNA yield and purity (A260/A280 ratio > 2.0) was estimated by a Nanodrop $^{\text {TM }} 1000$ Spectrophotometer (Thermo Fisher Scientific Inc.). RNA integrity was evaluated on $1.2 \%$ agarose gels. Purified RNA was stored at $-80{ }^{\circ} \mathrm{C}$. RNA was DNase treated with Amplification Grade DNase I (Invitrogen) and cDNA synthesis was done using iScript cDNA Synthesis kit as recommended (Biorad). In $20 \mu \mathrm{l}$ reactions $0.8 \mu \mathrm{g}$ RNA was used. No contamination of DNA in cDNA was verified in non RT samples. Expression analyses were done using 5 -fold diluted cDNA and ExTaq as polymerase as recommended (Takara Bio Inc.) in MyCycler (Biorad). Primers and gene specific reaction settings used in expression analysis are presented in Additional file 4. RT-PCR program; 4 min $94{ }^{\circ} \mathrm{C}, 25-32$ cycles of $\left[30 \mathrm{~s} 94{ }^{\circ} \mathrm{C}, 1 \min 55{ }^{\circ} \mathrm{C}, 1 \min 72{ }^{\circ} \mathrm{C}\right]$ and 7 min $72{ }^{\circ} \mathrm{C}$. Reactions for RT-qPCR were performed on an ICycler instrument (Bio-Rad) by using the iQ SYBR Green Supermix (Bio-Rad) according to supplier's 
instructions [61] using the program; $95{ }^{\circ} \mathrm{C}$ for $10 \mathrm{~min}$, 50 cycles of $\left[30 \mathrm{~s}\right.$ at $95^{\circ} \mathrm{C}, 1 \mathrm{~min}$ at $57.5^{\circ} \mathrm{C}$ and $1 \mathrm{~min}$ at $72{ }^{\circ} \mathrm{C}$ ]. To evaluate the efficiency of qPCR, serial dilutions of cDNA were used to generate a standard curve. This resulted in $\mathrm{R}^{2}$ values of 0.998 and 0.994 for $A C T$ and EIL2 primer sets, respectively. Threshold cycles (Ct), (defined as cycle were the signal exceeds ten times the standard deviation of the baseline), for CfEIL2 and Cmeil2 were standardized to the corresponding Actin $\mathrm{Ct}$ $(\Delta \mathrm{Ct})$. The relative quantification of target gene CfEIL2 and Cmeil2 between the different treatments was determined as $2^{\wedge}(-\Delta \Delta C t)$. Values are based on three replicates.

\section{Bioinformatics and statistics}

Sequence identification and analysis were done using CLC sequence viewer (CLC bio), BLAST and Clustal $\Omega$ [62]. Phylogenetic analysis were conducted using MEGA version 6.06 [63]. Statistical analyses were done in SigmaPlot v. 13 by one way analysis of variance using the Holm-Sidak method.

\section{Additional files}

Additional file 1: Alignment of partial sequences from translated Campanula ERS2 proteins. As a reference Arabidopsis thaliana (At) ERS2 is included [Genbank: P93825]. The first amino acids position in Arabidopsis cds is presented in brackets. Abbreviations are C. portenschlagiana (Cp), C. formanekiana $(\mathrm{C} f)$ and $\mathrm{C}$. medium $(\mathrm{Cm})$. Consensus among Arabidopsis and Campanula are marked with asterisk. The boxed areas enclose identical aa among Campanula ERS2. The alignment was produced in Clustal $\Omega$ [62]. (PDF $218 \mathrm{~kb}$ )

Additional file 2: Alignment of partial sequences from translated Campanula CTR1 proteins. As a reference Arabidopsis thaliana CTR1 aa 424-663 are included [Genbank: NP850760]. Abbreviations are C. portenschlagiana $(\mathrm{Cp}), \mathrm{C}$. formanekiana $(\mathrm{C} f)$ and C. medium $(\mathrm{Cm})$. Consensus among Arabidopsis and Campanula are marked with an asterisk. The alignment was produced in Clustal $\Omega$ [62]. (PDF 209 kb)

Additional file 3: Primers and PCR product sizes used for identification of sequences homologue to ERS2, CTR1, ElL and Actin in Campanula. (PDF $224 \mathrm{~kb}$ )

Additional file 4: Primers used for expression analysis of ERS2, CTR1, EIL1, EIL2 and Actin. (PDF $191 \mathrm{~kb}$ )

\section{Abbreviations}

1-MCP: 1-methylcyclopropene; Cf: Campanula formanekiana; Cm: Campanula medium; Cp: Campanula portenschlagiana; CTR: constitutive triple response; ElL: ethylene insensitive3-like; ERS: ethylene response sensor; RT-qPCR: quantitative reverse transcription PCR.

\section{Acknowledgements}

Gartneriet PKM A/S is greatly acknowledged for providing plant material and Christian Hald Madsen is thanked for fruitful discussions.

\section{Funding}

This study was funded by the Ministry of Higher Education and Science, Denmark.

\section{Availability of data and materials}

Data supporting findings in this study is contained within the manuscript or in supplementary files. Plant material except hybrids are commercially available from PKM A/S, Alpine Staudengärtnerei or Aigues-Vives as listed in
Methods. Genbank accession numbers for sequences described here are: CpERS2a (KX058423), CpERS2b (KM067692.1), CfERS2 (KM067690.1), CmERS2 (KM067691.1), CpCTR1 (KM067689.1), CfCTR1 (KM067687.1), CmCTR1 (KM067688.1), CpEIL1a (KX058425), CpEIL1b (KX058426), CFEIL1 (KX058 427), CfEIL2 (KX058428), CmEIL1 (KX058429), CmEIL2 (KX058430) and Actin (KX058424).

\section{Competing interests}

The authors have submitted a patent application covering parts of this work. The patent applied for is owned by the University of Copenhagen and Gartneriet PKM A/S

\section{Consent to publish}

Not applicable.

Ethics

Not applicable.

Received: 3 March 2016 Accepted: 14 April 2016

Published online: 23 May 2016

\section{References}

1. Abeles FB, Morgan PW, Saltveit ME. Ethylene in plant biology. 2nd ed. San Diego: Academic; 1992.

2. Bleecker AB, Estelle MA, Somerville C, Kende H. Insensitivity to ethylene conferred by dominant mutation in Arabidopsis thaliana. Science. 1988;241: $1-25$

3. Rodriguez Fl, Esch JJ, Hall AE, Binder BM, Schaller GE, Bleecker AB. A copper cofactor for the ethylene receptor ETR1 from Arabidopsis. Science. 1999; 283(5404):996-8.

4. Gamble RL, Coonfield ML, Schaller GE. Histidine kinase activity of the ETR1 ethylene receptor from Arabidopsis. Proc Natl Acad Sci U S A. 1998;95(13): 7825-9.

5. Moussatche P, Klee HJ. Autophosphorylation activity of the Arabidopsis ethylene receptor multigene family. J Biol Chem. 2004;279(47):48734-41.

6. Hua J, Sakai H, Nourizadeh S, Chen QG, Bleecker AB, Ecker JR, et al. EIN4 and ERS2 are members of the putative ethylene receptor gene family in Arabidopsis. Plant Cell. 1998;10(8):1321-32.

7. Clark KL, Larsen PB, Wang X, Chang C. Association of the Arabidopsis CTR1 Raf-like kinase with the ETR1 and ERS ethylene receptors. Proc Natl Acad Sci U S A. 1998;95(9):5401-6.

8. Kieber JJ, Rothenberg M, Roman G, Feldmann KA, Ecker JR. CTR1, a negative regulator of the ethylene response pathway in arabidopsis, encodes a member of the Raf family of protein kinases. Cell. 1993;72(3):427-41.

9. Alonso JM, Hirayama T, Roman G, Nourizadeh S, Ecker JR. EIN2, a bifunctional transducer of ethylene and stress responses in Arabidopsis. Science. 1999;284(5423):2148-52.

10. Ju C, Yoon GM, Shemansky JM, Lin DY, Ying ZI, Chang J, et al. CTR phosphorylates the central regulator EIN2 to control ethylene hormone signaling from the ER membrane to the nucleus in Arabidopsis. Proc Natl Acad Sci. 2012;109(47):19486-91.

11. Wen X, Zhang C, Ji Y, Zhao Q, He W, An F, et al. Activation of ethylene signaling is mediated by nuclear translocation of the cleaved EIN2 carboxyl terminus. Cell Res. 2012;22(11):1613-6.

12. Qiao H, Shen Z, Huang SC, Schmitz RJ, Urich MA, Briggs SP, et al. Processing and subcellular trafficking of ER-tethered EIN2 control response to ethylene gas. Science. 2012;338(6105):390-3.

13. Chao Q, Rothenberg M, Solano R, Roman G, Terzaghi W, Ecker JR. Activation of the ethylene gas response pathway in arabidopsis by the nuclear protein ETHYLENE-INSENSITIVE3 and related proteins. Cell. 1997;89(7):1133-44.

14. Chang KN, Zhong S, Weirauch MT, Hon G, Pelizzola M, Li H, et al. Temporal transcriptional response to ethylene gas drives growth hormone crossregulation in Arabidopsis. eLife. 2013;2, e00675.

15. Li Z, Peng J, Wen X, Guo H. Ethylene-insensitive3 is a senescence-associated gene that accelerates Age-dependent leaf senescence by directly repressing miR164 transcription in Arabidopsis. Plant Cell. 2013;25(9):3311-28.

16. Ferrante A, Trivellini A, Scuderi D, Romano D, Vernieri P. Post-production physiology and handling of ornamental potted plants. Postharvest Biol Tec. 2015;100:99-108.

17. Rogers HJ. From models to ornamentals: how is flower senescence regulated? Plant Mol Biol. 2013;82(6):563-574. 
18. Serek M, Woltering EJ, Sisler EC, Frello S, Sriskandarajah S. Controlling ethylene responses in flowers at the receptor level. Biotechnol Adv. 2006; 24(4):368-81.

19. Sun Y, Christensen B, Liu F, Wang H, Müller R. Effects of ethylene and 1-MCP (1-methylcyclopropene) on bud and flower drop in mini Phalaenopsis cultivars. Plant Growth Regul. 2009;59(1):83-91.

20. Woltering EJ. Effects of ethylene on ornamental pot plants: a classification. Sci Hort. 1987:31(3-4):283-94.

21. Müller $R$, Andersen AS, Serek M. Differences in display life of miniature potted roses (Rosa hybrida L.). Sci Hort. 1998;76(1-2):59-71.

22. Finlayson SA, Reid DM. Influence of $\mathrm{CO} 2$ on ACC oxidase activity from roots of sunflower (Helianthus annuus) seedlings. Phytochemistry. 1994 35(4):847-51.

23. Hansen H, Grossmann K. Auxin-induced ethylene triggers abscisic acid biosynthesis and growth inhibition. Plant Physiol. 2000;124(3):1437-48.

24. Lütken H, Clarke J, Müller R. Genetic engineering and sustainable production of ornamentals: current status and future directions. Plant Cell Rep. 2012;31(7):1141-57.

25. Chang C, Kwok S, Bleecker A, Meyerowitz E. Arabidopsis ethylene-response gene ETR1: similarity of product to two-component regulators. Science. 1993:262(5133):539-44.

26. Wilkinson JQ, Lanahan MB, Clark DG, Bleecker AB, Chang C, Meyerowitz EM, et al. A dominant mutant receptor from Arabidopsis confers ethylene insensitivity in heterologous plants. Nat Biotech. 1997;15(5):444-7.

27. Clevenger DJ, Barrett JE, Klee HJ, Clark DG. Factors affecting seed production in transgenic ethylene-insensitive petunias. J Amer Soc Hort Sci. 2004;129(3):401-6.

28. Sriskandarajah S, Mibus H, Serek M. Transgenic Campanula carpatica plants with reduced ethylene sensitivity. Plant Cell Rep. 2007;26(6): 805-13.

29. Shibuya K, Barry KG, Ciardi JA, Loucas HM, Underwood BA, Nourizadeh S, et al. The central role of PhEIN2 in ethylene responses throughout plant development in Petunia. Plant Physiol. 2004;136(2):2900-12.

30. Olsen A, Lütken $\mathrm{H}$, Hegelund JN, Müller R. Ethylene resistance in flowering ornamental plants - improvements and future perspectives. Horticulture Res. 2015;2:15038.

31. Heywood VH, Brummitt RK, Culham A, Seberg O. Flowering plant families of the world. Richmond: Kew Publishing; 2007.

32. Mansion G, Parolly G, Crowl AA, Mavrodiev E, Cellinese N, Oganesian M, et al. How to handle speciose clades? mass taxon-sampling as a strategy towards illuminating the natural history of Campanula (Campanuloideae). PLOS ONE. 2012;7(11), e50076.

33. Cameron AC, Reid MS. 1-MCP blocks ethylene-induced petal abscission of Pelargonium peltatum but the effect is transient. Postharvest Biol Tec. 2001; 22:169-77.

34. Porat $\mathrm{R}$, Halevy $\mathrm{AH}$, Serek $\mathrm{M}$, Borochov A. An increase in ethylene sensitivity following pollination is the initial event triggering an increase in ethylene production and enhanced senescence of Phalaenopsis orchid flowers. Physiol Plant. 1995;93(4):778-84.

35. Giblin DE. Variation in floral longevity between populations of Campanula rotundifolia (Campanulaceae) in response to fitness accrual rate manipulation. Am J Bot. 2005;92(10):1714-22.

36. Tanase K, Onozaki T, Satoh S, Shibata M, Ichimura K. Effect of Age on the auto-catalytic ethylene production and the expression of ethylene biosynthetic gene DCACS1 in petals of long-life carnations. Jpn Agric Res Q. 2011;45(1):107-16.

37. Hua J, Chang C, Sun Q, Meyerowitz E. Ethylene insensitivity conferred by Arabidopsis ERS gene. Science. 1995;269(5231):1712-4.

38. Ma N, Tan H, Liu X, Xue J, Li Y, Gao J. Transcriptional regulation of ethylene receptor and CTR genes involved in ethylene-induced flower opening in cut rose (Rosa hybrida) cv. Samantha. J Exp Bot. 2006;57(11):2763-73.

39. MöLler R, Lind-Iversen S, Stummann BM, Serek M. Expression of genes for ethylene biosynthetic enzymes and anethylene receptor in senescing flowers of miniature potted roses. J Hortic Sci Biotechnol. 2000;75(1):12-8.

40. Hua J, Meyerowitz EM. Ethylene responses Are negatively regulated by a receptor gene family in Arabidopsis thaliana. Cell. 1998;94(2):261-71.

41. Müller R, Stummann BM, Serek M. Characterization of an ethylene receptor family with differential expression in rose (Rosa hybrida L.) flowers. Plant Cell Rep. 2000;19(12):1232-9.

42. Shibuya K, Nagata M, Tanikawa N, Yoshioka T, Hashiba T, Satoh S. Comparison of mRNA levels of three ethylene receptors in senescing flowers of carnation (Dianthus caryophyllus L.). J Exp Bot. 2002;53(368): 399-406.

43. Müller R, Owen CA, Xue Z-T, Welander M, Stummann BM. Characterization of two CTR-like protein kinases in Rosa hybrida and their expression during flower senescence and in response to ethylene. J Exp Bot. 2002;53(371): 1223-5.

44. Hu H-L, Do Y-Y, Huang P-L. Expression profiles of a MhCTR1 gene in relation to banana fruit ripening. Plant Physiol Biochem. 2012;56:47-55.

45. Leclercq J, Adams-Phillips LC, Zegzouti H, Jones B, Latché A, Giovannoni JJ, et al. LeCTR1, a tomato CTR1-like gene, demonstrates ethylene signaling ability in Arabidopsis and novel expression patterns in tomato. Plant Physiol. 2002;130(3):1132-42.

46. Adams-Phillips L, Barry C, Kannan P, Leclercq J, Bouzayen M, Giovannoni J. Evidence that CTR1-mediated ethylene signal transduction in tomato is encoded by a multigene family whose members display distinct regulatory features. Plant Mol Biol. 2004;54(3):387-404.

47. Cho Y-H, Yoo S-D. Novel connections and gaps in ethylene signaling from the ER membrane to the nucleus. Front Plant Sci. 2015;5(733):1-7.

48. Bie BB, Pan JS, He HL, Yang XQ, Zhao JL, Cai R. Molecular cloning and expression analysis of the ethylene insensitive3 (EIN3) gene in cucumber (Cucumis sativus). Genet Mol Res. 2013;12(4):4179-91.

49. Yamasaki K, Kigawa T, Inoue $M$, Yamasaki T, Yabuki $T$, Aoki $M$, et al. Solution structure of the major DNA-binding domain of Arabidopsis thaliana ethylene-insensitive3-like3. J Mol Biol. 2005;348(2):253-64.

50. Rieu I, Mariani C, Weterings K. Expression analysis of five tobacco EIN3 family members in relation to tissue-specific ethylene responses. J Exp Bot. 2003;54(391):2239-44

51. Tieman DM, Ciardi JA, Taylor MG, Klee HJ. Members of the tomato LeEIL (EIN3-like) gene family are functionally redundant and regulate ethylene responses throughout plant development. Plant J. 2001;26(1): $47-58$

52. Yokotani N, Tamura S, Nakano R, Inaba A, Kubo Y. Characterization of a novel tomato EIN3-like gene (LeEIL4). J Exp Bot. 2003;54(393):2775-6.

53. Iordachescu M, Verlinden S. Transcriptional regulation of three EIN3-like genes of carnation (Dianthus caryophyllus L. cv. Improved White Sim) during flower development and upon wounding, pollination, and ethylene exposure. J Exp Bot. 2005:56(418):2011-8.

54. Wang $Y$, Zhang $C$, Jia $P$, Wang $X$, Wang W, Dong $L$. Isolation and expression analysis of three EIN3-like genes in tree peony (Paeonia suffruticosa). Plant Cell Tiss Org. 2013;112(2):181-90

55. Xu J, Zhang S. Regulation of ethylene biosynthesis and signaling by protein kinases and phosphatases. Mol Plant. 2014;7(6):939-42.

56. Kendrick MD, Chang C. Ethylene signaling: new levels of complexity and regulation. Curr Opin Plant Biol. 2008:11(5):479-85.

57. Röper AC, Lütken H, Christensen B, Boutilier K, Petersen KK, Müller R. Production of interspecific Campanula hybrids by ovule culture: exploring the effect of ovule isolation time. Euphytica. 2015;203(3):643-57.

58. Lusser M, Parisi C, Plan D, Rodríguez-Cerezo E. Deployment of new biotechnologies in plant breeding. Nat Biotechnol. 2012;30:231-9.

59. Belhaj K, Chaparro-Garcia A, Kamoun S, Nekrasov V. Plant genome editing made easy: targeted mutagenesis in model and crop plants using the CRISPR/Cas system. Plant Methods. 2013;9(1):39.

60. Benson DA, Cavanaugh M, Clark K, Karsch-Mizrachi I, Lipman DJ, Ostell J, et al. GenBank. Nucleic Acids Res. 2013;41(D1):D36-42.

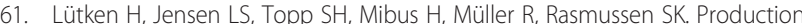
of compact plants by overexpression of AtSHI in the ornamental Kalanchoë. Plant Biotech J. 2010:8(2):211-22

62. McWilliam H, Li W, Uludag M, Squizzato S, Park YM, Buso N, et al. Analysis Tool Web Services from the EMBL-EBI. Nucleic Acids Res. 2013:41:W597-600.

63. Tamura K, Stecher G, Peterson D, Filipski A, Kumar S. MEGA6: Molecular Evolutionary Genetics Analysis version 6.0. Mol Biol Evol. 2013:30:2725-9. 